\title{
The Conversion Time of Cysts to Inactive form After Percutaneous Treatment of Hepatic Hydatid Disease and Predisposing Factors in This Process
}

\author{
Karaciğer Kist Hidatik Hastalığııın Perkütan Tedavisi Sonrasında, Kistin Inaktif \\ Formuna Dönüşüm Süresi ve Bu Süreci Etkileyen Faktörler \\ ๑ Bekir Turgut, ๑ Fatih Öncü \\ University of Health Sciences Turkey, Konya Training and Research Hospital, Clinic of Invasive Radiology, Konya, Turkey
}

\section{Abstract}

\begin{abstract}
Aim: This study aimed to evaluate the duration of cyst inactivation after percutaneous treatment of hepatic hydatid disease and the factors that may affect this process.
\end{abstract}

Methods: Ultrasound follow-up records were evaluated, and the criteria for cyst inactivation were determined. Cyst type, cyst size, and location were listed after scanning pre-treatment ultrasound reports. Percutaneous treatment technique, aspirated cyst content, complications, and duration of catheterization were listed. The time elapsed from percutaneous treatment to cyst inactivation was defined as inactivation time. Ultrasound follow-up period, cyst size at the last follow-up, and inactivation time were recorded.

Results: A total of 116 patients were included in the study. The mean follow-up period after treatment was $1003.95 \pm 293.23$ days. The mean inactivation time was $420.99 \pm 221.18$ days. The size of the inactivated cysts decreased significantly compared to the pre-treatment cyst size $(p=0.001)$. There was a positive correlation between cyst size and duration of catheterization $(p=0.0001)$. The inactivation time decreased with increased duration of catheterization $(p=0.001)$. There was a significant decrease in the inactivation time in patients who presented with complications ( $p=0.008)$.

Conclusion: Patients who develop complications after percutaneous treatment and patients with longer catheterization exhibit shorter cyst inactivation time.

Keywords: Hepatic, hydatid disease, hydatid cyst, cystic echinococcosis
Öz

Amaç: Bu çalışmanın amacı karaciğer kist hidatik hastalığının perkütan tedavi sonrasında kist inaktivasyon süresini ve bu süreci etkileyebilecek faktörleri değerlendirmektir.

Yöntemler: Takip ultrasonografi raporları değerlendirildi ve kist inaktivasyon kriterleri belirlendi. Tedavi öncesinde yapılmış olan ultrasonografi raporları taranarak kist tipi, kist boyutu ve lokalizasyonu listelendi. Uygulanan perkütan tedavi türü, kist içeriğinden gelen aspirat özelliği, komplikasyonlar, kateterizasyon süresi listelendi. Perkütan tedavi uygulama zamanından inaktif forma dönüşünceye kadar geçen süre, inaktivasyon süresi olarak tanımlandı. Ultrasonografi takip süresi, kistin son kontroldeki boyutu, inaktivasyon süresi kayıt edildi.

Bulgular: Toplamda 116 hasta verileri çalışmaya dahil edildi. Tedavi sonrası ortalama takip süresi $1003,95 \pm 293,23$ gün olmuştur. Ortalama inaktivasyon süresi 420,99 $\pm 221,18$ gün oldu. Tedavi öncesi kist boyutuna kıyasla inaktive olmuş kistlerde boyut anlamlı olarak azalmaktadır $(p=0,001)$. Kist boyutu ile kateterizasyon süresi arasında pozitif bir korelasyon gözlendi ( $p=0,0001)$. Kateterizasyon süresi arttıkça inaktivasyon süresi azaldı $(p=0,001)$. Komplikasyon gelişen hasta grubunda inaktivasyon süresinde anlamlı olarak azalma oldu $(p=0,008)$.

Sonuç: Perkütan tedavi sonrasında komplikasyon gelişen veya kateterizasyonun daha uzun süre olduğu hastalarda kist inaktivasyon süresi kısalmaktadır.

Anahtar Sözcükler: Karaciğer, hidatik hastalık, hidatik kist, kistik ekinokokuz
Address for Correspondence/Yazışma Adresi: Bekir Turgut, University of Health Sciences Turkey, Konya Training and Research Hospital, Clinic of Invasive Radiology, Konya, Turkey E-mail: drbekirturgut@gmail.com ORCID: orcid.org/0000-0001-8276-9996 Received/Geliş Tarihi: 15 January 2020 Accepted/Kabul Tarihi: 07 April 2020
${ }^{\circ}$ Copyright 2020 by The Medical Bulletin of istanbul Haseki Training and Research Hospital The Medical Bulletin of Haseki published by Galenos Yayınevi. ${ }^{\circledR}$ Telif Hakkı 2020 Istanbul Haseki Eğitim ve Araştırma Hastanesi Haseki Tıp Bülteni, Galenos Yayınevi tarafından yayınlanmıştır. 


\section{Introduction}

Humans are an accidental intermediate host for cystic echinococcosis (CE), also known as hydatid disease (1). It is known to be endemic all over the world, especially in rural areas (2). The liver is the most commonly affected organ by the parasite (3). Three therapeutic modalities exist to treat hepatic CE: chemotherapy, surgery, and percutaneous drainage (4).

Percutaneous methods have been preferred in the treatment of hepatic hydatid disease in recent years as they are minimally invasive with low mortality and high technical success rate (5-7). Especially in the last two decades, different methods such as puncture, aspiration, injection, and re-aspiration (PAIR), standard catheterization technique with hypertonic saline and ethanol (PAIDS), and modified catheterization (MoCAT) have been successfully used in the treatment of hepatic hydatid cysts (8-11).

CE cysts are classified as active (CE1, CE2), transitional (CE3a and CE3b), and inactive (CE4, CE5) according to the World Health Organization Informal Working Group on Echinococcosis (WHO-IWGE) ultrasound (US) classification (12). It is recommended to categorize hydatid cysts according to the CE classification along with a follow-up period of 5 years with US after percutaneous treatment (13). Percutaneous treatment aims to convert active and transitional liver cysts to inactive form (14).

Available studies have mostly examined the success of medical, surgical, and percutaneous treatment methods. However, follow-up of the cysts after percutaneous treatment, follow-up period, inactivation time, and predisposing factors affecting this inactivation time were neglected. This study aimed to evaluate the inactivation time of hepatic hydatid cyst after percutaneous treatment and the factors that may affect this process.

\section{Methods}

\section{Ethical}

All procedures performed in studies involving human participants were in accordance with the ethical standards of the institutional and/or national research committee and with the 1964 Helsinki Declaration and its later amendments or comparable ethical standards. This work was approved by the local ethics committee, Necmettin Erbakan University Meram Faculty of Medicine, Medicine and Non-medical Devices Ethics Committee (decision year and no: 2020/2270).

\section{Study Plan and Patients}

The study was planned retrospectively in the interventional radiology unit of the institution. Hospital records of 177 patients with hepatic hydatid cysts, who underwent percutaneous treatment between January
2016 and December 2018, were retrospectively screened. Follow-up US was done before and after treatment by an interventional radiologist. The US reports were recorded on the system as soon as they were made. Posttreatment 1 st $, 3^{\text {rd }}, 6^{\text {th }}, 9^{\text {th }}, 12^{\text {th }}, 24^{\text {th }}, 36^{\text {th }}, 48^{\text {th }}$ and $60^{\text {th }}$ months follow-up records of patients, who underwent percutaneous treatment according to the diagnosis and follow-up standards of the WHO-IWGE US classification, were evaluated. In these reports, the number of cysts, type of cysts, membrane degeneration of the cyst and solidification features of the cyst were indicated. Cysts with no identified change in size and content and purulent cystic appearance with intact inner membrane were considered signs of unsuccessful treatment. The development of new daughter vesicles was accepted as recurrence. Decreased cyst size, along with the absence of daughter vesicles or pure cystic appearance, was defined as desirable criteria for cyst inactivation. On the contrary, complete obliteration of the cyst cavity and complete solid cyst content with no fluid component were defined as inactivation criteria alone (Figure 1). Decreased cyst size with shrunken, collapsed, solidified inner membrane, and more than $50 \%$ solidification of cyst content was accepted as inactivation (Figure 2) (8-17).

Thirty-six patients, who did not regularly show up or those who did not attend US follow-up visits, were excluded. Another 25 patients, who were scheduled for US follow-up in a different institution, whose reports did

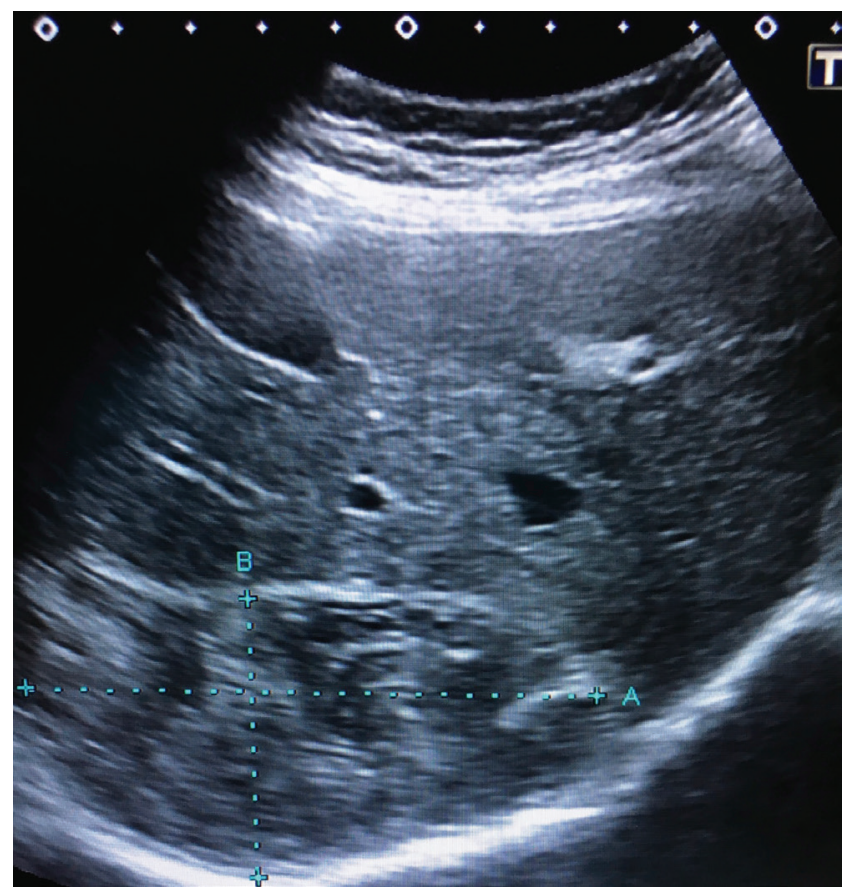

Figure 1. The cyst, which was $20 \times 12.6 \mathrm{~cm}$ in size before the treatment, decreased to $8.7 \times 4.5 \mathrm{~cm}$ at 3-year follow up with a solid cystic content form without any fluid component 
not comply with our US evaluation format, were excluded from the study. A total of 61 patients were excluded from the study. Medical records and US scans of the remaining 116 patients were analyzed retrospectively using the hospital data processing and communication system.

Age and gender were recorded. Recorded US reports made before and after treatment by the interventional radiologist were examined. Cyst type, cyst size, and location were listed by the interventional radiology specialist after scanning the pre-treatment US reports. Treatment type, aspirated cyst content, complications, and duration of catheterization were listed using the records of percutaneous treatment and patient reports. Inactivation time was defined as the time elapsed from the time of percutaneous treatment to conversion to the inactive form. Follow-up period, cyst size at the last followup, and inactivation time were recorded using US followup reports.

\section{Statistical Analysis}

Statistical analysis was done using the Statistical Package for Social Sciences (SPSS) for Windows 22.0

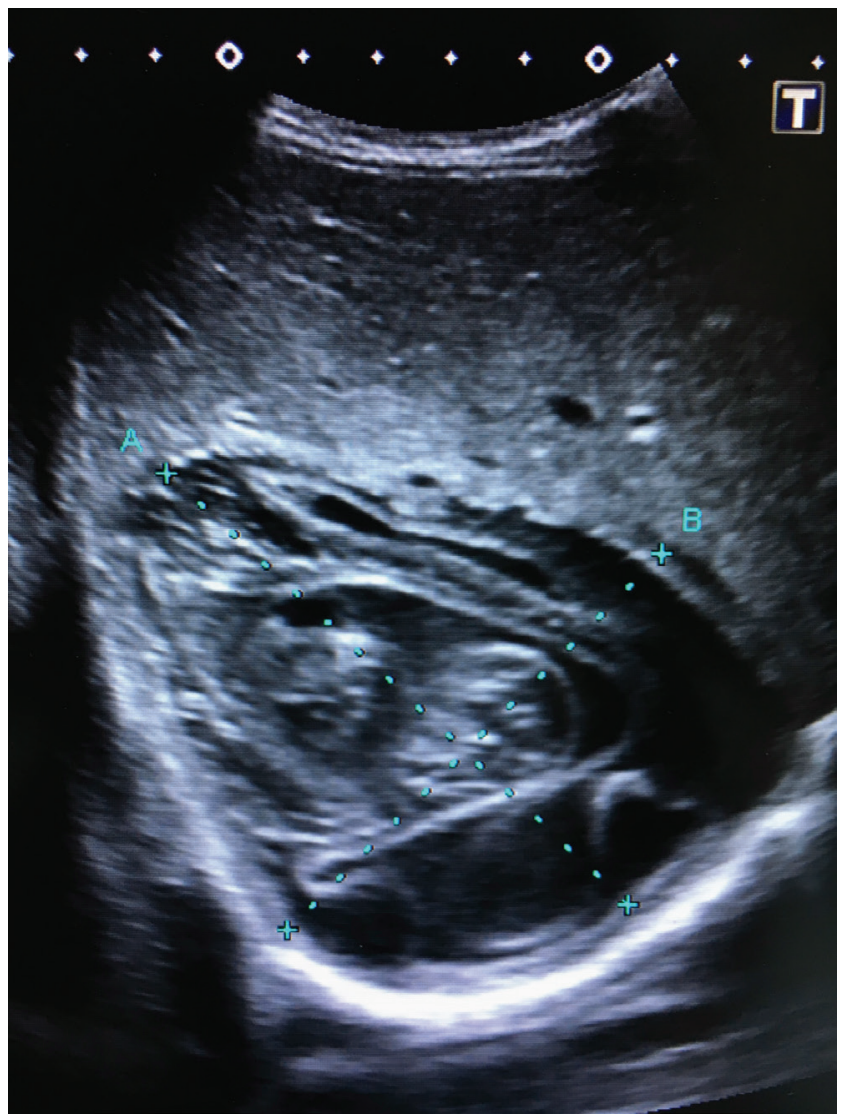

Figure 2. Decreased cyst appearance with more than $50 \%$ solidification of cyst content at 1-year follow-up in a patient treated using the standard catheterization technique with 12 days of catheterization
(SPSS Inc, Chicago, IL). Descriptive statistics are presented as median (25-75\%), frequency distributions, and percentages. Visual (histogram and probability graphs) and analytical (Kolmogorov-Smirnov test) methods were used to assess the conformity of the quantitative data to the normal distribution.

The independent samples t-test was used to assess the correlation between gender and location variables and inactivation time. Simple linear regression was used to evaluate the effects of complications, aspirated cyst content, treatment technique, and cyst type on inactivation time. The one-sample t-test was used to evaluate the significance of the difference between pre-treatment cyst size and inactivated cyst size. Correlation analysis was done to evaluate the correlation between cyst size, inactivation time, and duration of catheterization. The one-way ANOVA test was used to evaluate the effect of variables of cyst type, treatment technique, and aspirated cyst content on inactivation time. Pearson's chi-squared test was used to evaluate the relationship between different treatment techniques, variable cyst types, and complications such as CBF and abscess. The level of statistical significance was accepted as $p<0.05$.

\section{Evaluation Before Percutaneous Treatment}

All patients were evaluated with US by the interventional radiologist prior to treatment. Albendazole was administered orally at a dose of $10 \mathrm{mg} / \mathrm{kg} /$ day for prophylaxis to reduce the risk of secondary dissemination 10 days before percutaneous treatment. The same dose was continued for 15 days after treatment.

\section{Percutaneous Treatment and Follow-up Procedures}

All percutaneous treatment procedures were performed by two interventional radiologists with at least 3 years of experience. Treatment procedures were carried out under aseptic conditions with US or fluoroscopic guidance.

The PAIR procedure was used for the treatment of CE1 and CE3 cysts $\leq 5 \mathrm{~cm}$. The PAIDS procedure was used for the treatment of CE1 and CE3 cysts $>5 \mathrm{~cm}$. The MoCAT procedure was used for the treatment of CE2 cysts and cysts with purulent contents. Thirty percent hypertonic saline was used as a scolicidal agent, while 95\% ethyl alcohol was used as a sclerosing agent. The PAIDS and MoCAT procedures were initiated by following the same PAIR protocols and stages. Catheters of different thicknesses were inserted. A 6-8 F thick catheter (Bioteq, Taipei, Taiwan) was inserted into the cystic cavity in the PAIDS technique, while a 10-14 F catheter (Bioteq, Taipei, Taiwan) was used in the MoCAT technique. A collection bag was then attached to the tip of the catheter for 


\begin{tabular}{|c|c|c|c|c|}
\hline & CE1 & CE2 & CE3 & $\mathrm{p}$ \\
\hline Age, mean $( \pm S D)$ & $45.68(19.06)$ & $32.86(21.36)$ & $39.84(21.52)$ & 0.379 \\
\hline \multicolumn{5}{|l|}{ Gender, n (\%) } \\
\hline Male & $24(26.7)$ & $3(42.9)$ & $8(42.1)$ & \multirow{2}{*}{0.086} \\
\hline Female & $66(73.3)$ & $4(57.1)$ & $11(57.9)$ & \\
\hline \multicolumn{5}{|l|}{ Localization, n (\%) } \\
\hline Left & $21(23.3)$ & $0(0.0)$ & $6(31.6)$ & \multirow{2}{*}{0.912} \\
\hline Right & $69(76.7)$ & $7(100)$ & $13(68.4)$ & \\
\hline Pretreatment cyst size, $(\mathrm{cm})$ mean $( \pm \mathrm{SD})$ & $8.65(3.78)$ & $7.36(3.30)$ & $10.22(5.47)$ & 0.086 \\
\hline \multicolumn{5}{|l|}{ Treatment, n (\%) } \\
\hline PAIDS & $53(58.9)$ & $3(42.9)$ & $11(57.9)$ & \multirow{3}{*}{0.598} \\
\hline MoCAT & $12(13.3)$ & $3(42.9)$ & $4(21.1)$ & \\
\hline PAIR & $25(27.8)$ & $1(14.3)$ & $4(21.1)$ & \\
\hline \multicolumn{5}{|l|}{ Aspirate, $\mathrm{n}(\%)$} \\
\hline Hydatid sand & $83(92.2)$ & $6(85.7)$ & $11(57.9)$ & \multirow{3}{*}{0.138} \\
\hline Yellow-colored & $4(4.4)$ & $0(0.0)$ & $1(5.3)$ & \\
\hline Purulent liquid & $3(3.3)$ & $1(14.3)$ & $7(36.8)$ & \\
\hline Duration of catheterization, (day) mean \pm SD & $6.03(14.87)$ & $3.33(2.73)$ & $9.20(13.06)$ & 0.001 \\
\hline \multicolumn{5}{|l|}{ Complication, $\mathrm{n}(\%)$} \\
\hline None & $83(92.2)$ & $7(100)$ & $18(94.7)$ & \multirow{2}{*}{0.721} \\
\hline Yes & $7(7.8)$ & $0(0.0)$ & $1(5.3)$ & \\
\hline Follow-up period, (day) mean $( \pm S D)$ & $1031.16(286.77)$ & $865.71(245.96)$ & $926.05(324.12)$ & 0.203 \\
\hline Cyst final size, $(\mathrm{cm})$ mean $( \pm \mathrm{SD})$ & $4.91(2.11)$ & $4.94(2.58)$ & $5.83(2.80)$ & 0.125 \\
\hline Cyst inactivation time, (day) mean ( \pm SD) & $409.50(212.65)$ & $349.29(156.46)$ & $501.84(266.93)$ & 0.173 \\
\hline Total, n (\%) & 90 (77.6) & $7(6)$ & $19(16.4)$ & - \\
\hline
\end{tabular}

free drainage. Ethanol sclerotherapy and aspiration were performed after 24 hours if no fistulas were observed. Additionally, in the MoCAT technique, the catheter was rotated around its axis inside the cyst and the cyst was irrigated daily with physiological saline until the aspirated fluid and cyst contents became clear. These procedures were repeated until all cysts, daughter vesicles, and septations were cleared. In both procedures, the catheter was removed once the output was less than $10 \mathrm{cc}$ and clear.

After the treatment, the patients were taken to the observation units. Patients, who underwent the PAIR procedure, were discharged after 6 hours if no complications occurred. Patients, who underwent catheterization, were discharged 1 day after the catheters were removed. At the 1 st $, 3^{\text {rd }}, 6^{\text {th }}, 9^{\text {th }}, 12^{\text {th }}, 24^{\text {th }}, 36^{\text {th }}, 4^{\text {th }}$ and $60^{\text {th }}$ months, US follow-ups were performed.

\section{Results}

A total of 116 patients (35 males, 81 females) were included in the study. The mean age of the patients was $43.94 \pm 19.74$ years. The PAIDS technique was the most preferred procedure with $57.8 \%$ (Table 1). The follow-up period in the interventional radiology unit was between 270 and 1340 days. The mean follow-up period after treatment was $1003.95 \pm 293.23$ days. The mean inactivation time was $420.99 \pm 221.18$ days. The mean pre-treatment cyst size was $8.82 \pm 4.10 \mathrm{~cm}$. The mean final cyst size in inactivated cysts was $5.06 \pm 2.26 \mathrm{~cm}$. A significant decrease was observed in cyst size in which inactivation was achieved compared to the pre-treatment cyst size $(p=0.001)$. The effect of age, lesion location, and treatment technique on cyst inactivation time was not statistically significant $(p=0.379, p=0.356, p=0.912$ and $p=0.598$, respectively).

The most common aspirate after cyst puncture was hydatid sand. The mean inactivation time was $412.35 \pm 205.56$ days in patients with hydatid and aspirate, $506.00 \pm 326.92$ days in patients with a yellow-colored aspirate, and $460.90 \pm 308.89$ days in patients with the purulent aspirate $(p=0.370)$. The mean inactivation time was $482.42 \pm 268.26$ days in male patients and 
394.44 \pm 193.32 days in female patients. Inactivation time was significantly shorter in female patients ( $p=0.049$ ).

The overall mean inactivation time was $420.99 \pm 221.18$ days. Among the CE1, CE2, and CE3 cysts, the shortest inactivation time was $349.28 \pm 156.45$ in the CE2 cyst group. However, the effect of different cyst types on inactivation time was not statistically significant $(p=0.173)$.

The mean duration of catheterization was $6.39 \pm 14.09$ days in the PAIDS and MoCAT procedures. The mean duration was $1.94 \pm 1.25$ days in the PAIDS procedure and $22.11 \pm 24.33$ days in the MoCAT procedure. The longest catheterization duration in the CE3 cyst group was $9.20 \pm 3.06$ days. There was a significant difference in the duration of catheterization among the CE1, 2, 3 cyst groups $(p=0.001)$. A positive correlation was observed between cyst size and duration of catheterization (Pearson correlation coefficient $p=0.333, p=0.0001$ ) with longer catheterization resulting in shorter inactivation time $(p=0.001)$.

Post-treatment complications were observed in eight $(6.9 \%)$ patients. Three (2.6\%) patients developed an abscess while five (4.3\%) patients developed a cysto-biliary fistula (CBF). Complications occurred in one (3.3\%) of 30 patients undergoing the PAIR procedure, in six (31.6\%) of 19 patients undergoing the MoCAT procedure, and in one $(1.5 \%)$ of 67 patients undergoing catheterization. The incidence of CBF and abscess was significantly higher in patients requiring MoCAT procedure $(p=0.001)$. The mean inactivation time was $435.78 \pm 216.60$ days in patients who did not develop complications. The mean inactivation time was $133.33 \pm 145.11$ days in patients developing abscess and $274.00 \pm 214.51$ days in patients developing CBF. There was a significant decrease in the inactivation time among patients who developed complications $(p=0.008)$.

Two patients received additional percutaneous treatment. Increased cyst size was noted in the first patient at the 3-month follow-up and in the second patient at the 6-month follow-up. It was considered as recurrence or unsuccessful treatment, and additional percutaneous treatment was performed. No dissemination was observed in other hepatic segments in any patient.

\section{Discussion}

In this study, the long-term outcomes of percutaneous treatment of hydatid cysts were evaluated. The duration of cyst inactivation, which was aimed at the treatment, and predisposing factors affecting this process were assessed. A significant decrease was observed in the size of the cysts in which inactivation was achieved compared to the pre-treatment cyst size. A positive correlation was noted between cyst size and duration of catheterization. Shorter inactivation time was observed in patients who developed complications and had longer catheterization. It was proved that the cyst inactivation time was shorter in patients who underwent additional catheter treatment and longer primary catheterization due to the development of complications.

The risk of the CBF is high in cysts measured larger than $8 \mathrm{~cm}$ prior to hepatic hydatid treatment $(p=0.007)$ (18). Similarly, some studies reported a higher incidence of CBF in cysts larger than $8.5 \mathrm{~cm}$ (19). Polat et al. (20) published long-term results of patients undergoing percutaneous treatment of hepatic hydatid cysts with a mean follow-up of $54 \pm 5.4$ months. They reported a progressive and statistically significant decrease in cyst size and an alteration in cyst appearance during the inactivation process. The initial cyst size was 7.5 \pm 2.9 $\mathrm{cm}$, while the cyst diameter decreased to $3.2 \pm 1.5 \mathrm{~cm}$ in the last follow-up period $(p<0.001)$. None of these three studies evaluated the effects of other variables such as duration of catheterization, except for size, on inactivation time. This study reported patient records with a mean follow-up period of $1003.95 \pm 293.23$ days. The mean pre-treatment cyst size was $8.82 \pm 4.10 \mathrm{~cm}$, and the cyst size decreased to $5.06 \pm 2.26 \mathrm{~cm}$ in the cysts achieving inactivation. In this study, the cyst size decreased significantly during the inactivation process, which was consistent with other studies $(p=0.001)$. Besides, as a complement to the above-mentioned studies, the correlation between cyst size and duration of catheterization was also evaluated. The relationship of inactivation time with cyst size and duration of catheterization was demonstrated. There was a positive correlation between the cyst size and the duration of the catheterization in percutaneous treatment procedures (PAIDS and MoCAT) with catheters $(p=0.0001)$. Both the largest mean cyst size and the longest mean catheterization were observed in the CE3 cyst group $(p=0.001)$. Inactivation time was shorter in these larger cysts with longer duration of catheterization. There was a negative correlation between the duration of catheterization and the inactivation time, while a positive correlation was observed with cyst size.

In conclusion: Complications are more common in larger cysts. Additional catheter treatment and longer catheterization are required in cases who present with complications. The amount of aspirated cystic fluid contents and fragmented membranes increases with longer catheterization. This situation may lead to rapid inactivation and reduced inactivation time.

Complications such as abscess or CBF may be observed secondary to percutaneous treatment (21). Percutaneous catheter drainage and medical treatment can be used in the treatment of abscesses (22). The communication between 
the cyst and the biliary system due to cyst decompression (CBF development) is a complication easily manageable by endoscopy (23). Turan et al. (24) conducted a study comparing two percutaneous methods and found that the complication rate of the Trocar technique was 6.1\%, while that of the Seldinger technique was $17.9 \%$. The Seldinger technique has a higher rate of complications. A detailed evaluation reveals that no local recurrence occurs, and all cysts are inactivated with the Seldinger technique. This occurrence suggests that complications may contribute to the inactivation process. However, they overlooked these significant findings and did not evaluate the effect of complications on the inactivation process. The present study demonstrated that inactivation time was significantly lower in patients who developed an abscess and CBF compared to those who did not $(p=0.008)$. Complications and associated additional percutaneous procedures play a significant role in the inactivation process. Accumulation of different cystic fluids, such as abscesses or bile, may also affect cyst inactivation. In addition, removal of cyst fluid content and other membranous structures during the treatment of these complications may accelerate inactivation.

\section{Study Limitations}

This study has some limitations. First, all patient followups were performed using US. It is known that US is reliable for detecting pathognomonic symptoms of CE (25). US is a simultaneously applied method. Therefore, it is not an imaging tool suitable for data recording and storage. We could not re-evaluate the follow-up US scans retrospectively. However, the study was not negatively affected as our report format, and assessment standard were set according to the diagnosis and follow-up standards of the World Health Organization (WHO) CE classification. Second, the majority of the US follow-up reports of patients, performed in other institutions, did not comply with the diagnosis and follow-up standards of the WHO CE classification. These patients were excluded from the study to avoid any inconsistency. In this regard, the number of patients excluded from this study was higher than expected. However, the remaining patient group was sufficient for the significance of statistical analyses.

\section{Conclusion}

Decreased cyst size during the US follow-up period after percutaneous treatment of hydatid cysts is indicative of inactivation. Additionally, catheterization is longer in larger cysts, which contributes to decreased inactivation time. Subsequent complications, such as abscesses and cyst-biliary fistula, reduce the duration of inactivation.

Inactivation time is shorter in cases undergoing longer catheterization for the extraction of the fluid content and membranous structures of the cyst in the percutaneous treatment of hepatic hydatid cysts.

\section{Authorship Contributions}

Concept: B.T. Design: B.T., F.Ö. Data Collection or Processing: B.T., F.Ö. Analysis or Interpretation: B.T., F.Ö. Literature Search: B.T., F.Ö. Writing: B.T.

Conflict of Interest: No conflict of interest was declared by the authors.

Financial Disclosure: The authors declared that this study received no financial support.

\section{References}

1. Erol M, Yiğit Ö, Toksöz M, et al. Akciğer semptomları ile bulgu veren kist hidatikli olgularımızın değerlendirilmesi. Med Bull Haseki 2015;53:147-52.

2. Özer B, Kocakuşak A, Benek S, et al. Karaciğer kist hidatiğinde parsiyel kistektomi ve tüp drenaj tekniğinin diğer cerrahi metodlarla karşilaştirilmasi. Med Bull Haseki 2014;52:287-90.

3. Pedrosa I, Saíz A, Arrazola J, Ferreiro's J, Pedrosa CS. Hydatid disease: radiologic and pathologic features and complications. RadioGraphics 2000;20:795-817.

4. Smego RA Jr, Sebanego P. Treatment options for hepatic cystic echinococcosis. Int J Infect Dis 2005;9:69-76.

5. Giorgio A, de Stefano G, Esposito V, et al. Longterm results of percutaneous treatment of hydatid liver cysts: a single center 17 years experience. Infection 2008;36:256-61.

6. Akhan $O$, Yildiz AE, Akinci $D$, Yildiz BD, Ciftci $T$. Is the adjuvant albendazole treatment really needed with PAIR in the management of liver hydatid cysts? A prospective, randomized trial with short-term follow-up results. Cardiovasc Intervent Radiol 2014;37:1568-74.

7. Kabaalioğlu A, Ceken K, Alimoglu E, Apaydin A. Percutaneous imaging-guided treatment of hydatid liver cysts: Do long-term results make it a first choice? European Journal of Radiology 2006;59:65-73.

8. Schipper HG, Lameris JS, van Delden OM, et al. Percutaneous evacuation (PEVAC) of multivesicular echinococcal cysts with or without cystobiliary fistulas which contain non-drainable material: first results of a modified PAIR method. Gut 2002;50:718-23.

9. Gabal AM, Khawaja FI, Mohammad GA. Modified PAIR technique for percutaneous treatment of high risk hydatid cysts. Cardiovasc Intervent Radiol 2005;28:200-8.

10. Akhan O, Salik AE, Ciftci T, Akinci D, Islim F, Akpinar B. Comparison of long-term results of percutaneous treatment techniques for hepatic cystic echinococcosis types 2 and 3b. AJR Am J Roentgenol 2017;208:878-84.

11. Popa AC, Akhan O, Petruţescu MS, et al. New options in the management of cystic echinococcosis - a single centre experience using minimally Invasive techniques. Chirurgia (Bucur) 2018;113:486-96. 
12. WHO Informal Working Group. International classification of US images in cystic echinococcosis for application in clinical and field epidemiological settings. Acta Trop 2003;85:25361.

13. Wen $H$, Vuitton L, Tuxun $T$, et al. Echinococcosis: Advances in the 21st Century. Clin Microbiol Rev 2019;32:pii:e00075-18.

14. Akhan O, Gumus B, Akinci D, Karcaaltıncaba M, Ozmen M. Diagnosis and percutaneous treatment of soft tissue hydatid cysts. Cardiovasc Intervent Radiol 2007;30:419-25.

15. Turgut AT, Akhan O, Bhatt S, Dogra VS. Sonographic spectrum of hydatid disease. Ultrasound Q 2008;24:17-29.

16. Pendse HA, Nawale AJ, Deshpande SS, Merchant SA. Radiologic features of hydatid disease: the importance of sonography. J Ultrasound Med 2015;34:895-905.

17. Brunetti E, Tamarozzi F, Macpherson C, et al. Ultrasound and cystic echinococcosis. Ultrasound Int Open 2018;4:70-8.

18. Akkapulu N, Aytac HO, Arer IM, Kus M, Yabanoglu $H$. Incidence and risk factors of biliary fistulation from hepatic hydatid cyst in clinically asymptomatic patients. Trop Doct 2018;48:20-4.

19. Demircan O, Baymus M, Seydaoglu G, Akinoglu A, Sakman G. Occult cystobiliary communication presenting as postoperative biliary leakage after hydatid liver surgery: are there significant preoperative clinical predictors? Can J Surg 2006;49:177-84.

20. Polat $K Y$, Balik AA, Oren D. Percutaneous drainage of hydatid cyst of the liver: long-term results. HPB (Oxford) 2002;4:1636.

21. Ambregna S, Koch S, Sulz MC, et al. A European survey of perendoscopic treatment of biliary complications in patients with alveolar echinococcosis. Expert Rev Anti Infect Ther 2017; 15:79-88.

22. Barosa R, Pinto J, Caldeira A, Pereira E. Modern role of clinical ultrasound in liver abscess and echinococcosis. J Med Ultrason 2017;44:239-45.

23. Villán González A, Pérez Pariente JM, Barreiro Alonso E. Obstructive jaundice secondary to a hepatic hydatid cyst. Rev Esp Enferm Dig 2018;110:741-2.

24. Turan HG, Özdemir M, Acu R, et al. Comparison of seldinger and trocar techniques in the percutaneous treatment of hydatid cysts. World J Radiol 2017; 9:405-12.

25. Macpherson CN, Bartholomot B, Frider B. Application of ultrasound in diagnosis, treatment, epidemiology, public health and control of Echinococcus granulosus and $E$. multilocularis. Parasitology 2003;127:21-35. 